\title{
SUNFLOWER BROOMRAPE (Orobanche cumana Wallr.) IN CASTILLA-LEÓN, A TRADITIONALLY NON- BROOMRAPE INFESTED AREA IN NORTHERN SPAIN
}

Fernández-Escobar, J. ${ }^{*}$, Rodríguez-Ojeda, M.I. ${ }^{1}$,

Fernández-Martínez, J.M. ${ }^{2}$ and Alonso, L.C. ${ }^{1}$

${ }^{1}$ Koipesol Semillas S.A. Avd. San Fco Javier 24. Ed. Sevilla 1 planta 7.

41018 Sevilla (Spain)

${ }^{2}$ Instituto de Agricultura Sostenible (CSIC). C/ Alameda del Obispo s/n.

14080 Córdoba (Spain)

Received: July 15, 2009 Accepted: November 10, 2009

\section{SUMMARY}

Spanish sunflower acreage is basically divided into three main and isolated areas, the Guadalquivir valley, southern Spain, represents $37 \%$ of the total acreage, the Cuenca area located in Spain's central plateau, 28\%, and the Castilla-León area, northern Spain, 29\%. Sunflower broomrape (Orobanche cumana Wallr.) has been present in Spain since the 1960's. From that time on, different waves of dissemination and dispersion of the parasite have been registered. The latest correspond to the broomrape race $\mathrm{E}$ dispersal in the early 1990 's and race F dispersal in the first few years of this century. These broomrape dissemination waves have been limited only to the Guadalquivir and Cuenca areas. In the Castilla-León area, the presence of broomrape had not been noticed until now.

In 2008, a highly virulent broomrape infection focal point (about $300 \mathrm{~m}^{2}$ ) was detected in a sunflower plot near Medina del Campo (Valladolid), south of the center of the Castilla-León area. Racial determination has proved that this broomrape inoculum belongs to race $\mathrm{F}$.

Key words: broomrape, dissemination, $\mathrm{F}$ race, Orobanche cumana, sunflower

\section{INTRODUCTION}

Sunflower broomrape (Orobanche cumana Wallr.) is responsible for severe infestations of cultivated sunflower in many countries - Spain, the Black Sea countries, Ukraine and China (Sackton, 1992; Parker, 1994; Melero-Vara et al., 2000) where it is considered to be the most serious sunflower disease. This obligate hol-

* Corresponding author: Phone: +34-954190800 Fax: +34-954191248;

e-mail: juan.fernandez@koipesolsemillas.com 
oparasite attaches itself to the sunflower roots competing with the host plant for water and nutrients and thus causing important yield losses that can reach up to 50\% (Dominguez 1996).

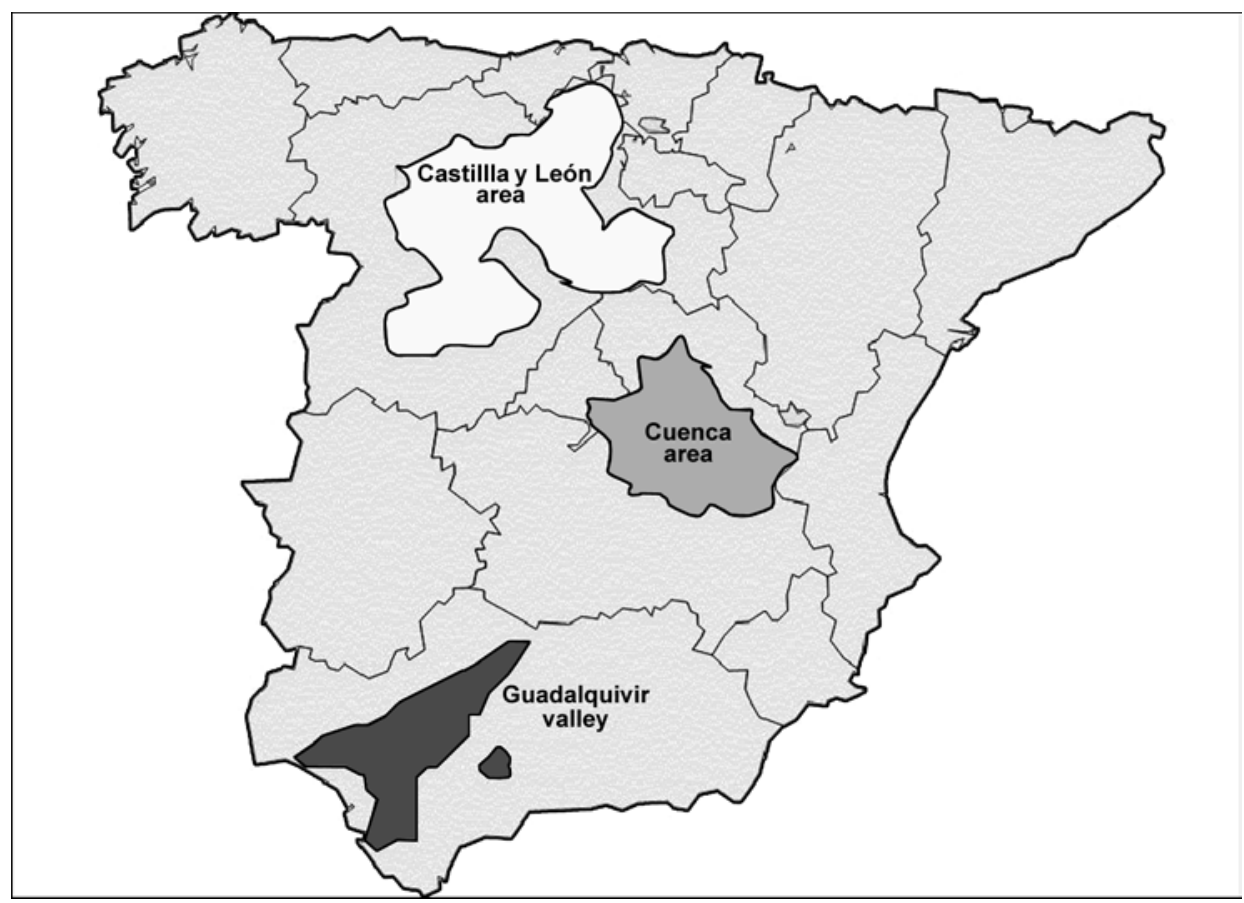

Figure 1: Distribution of the sunflower crop in Spain

Sunflower acreage in Spain is basically distributed in three main and mutually isolated areas (Figure 1), Guadalquivir valley in Andalusia, southern Spain, with $35-40 \%$ of the total acreage in the last five years, Cuenca area located in the central plateau of Spain, with 25-30\%, and Castilla-León area situated in northern Spain that represents the $25-30 \%$ of the total acreage.

In Spain, broomrape was detected first in the Toledo Province (central plateau) in 1958, infecting confectionery sunflower (Gonzalez Torres et al., 1982). During the 1960s and 1970s, broomrape was located in some areas of both Cuenca and Guadalquivir valley, always associated with confectionery sunflower crops.

The first news of oil sunflower being infected by broomrape was in the 1980s. During the 1990s, the broomrape infestation had spread over wide areas of Cuenca and the Guadalquivir valley, infecting all commercial hybrids available at that moment (Alonso, 1998). Racial studies of several inocula collected in Cuenca and Guadalquivir areas showed that they belonged to race E (Melero-Vara, 1999; Domínguez, 2004). At the end of the 1990s most of the commercial hybrids sown in these areas were resistant to broomrape race $\mathrm{E}$, most of those carrying the $\mathrm{Or}_{5}$ gene. 


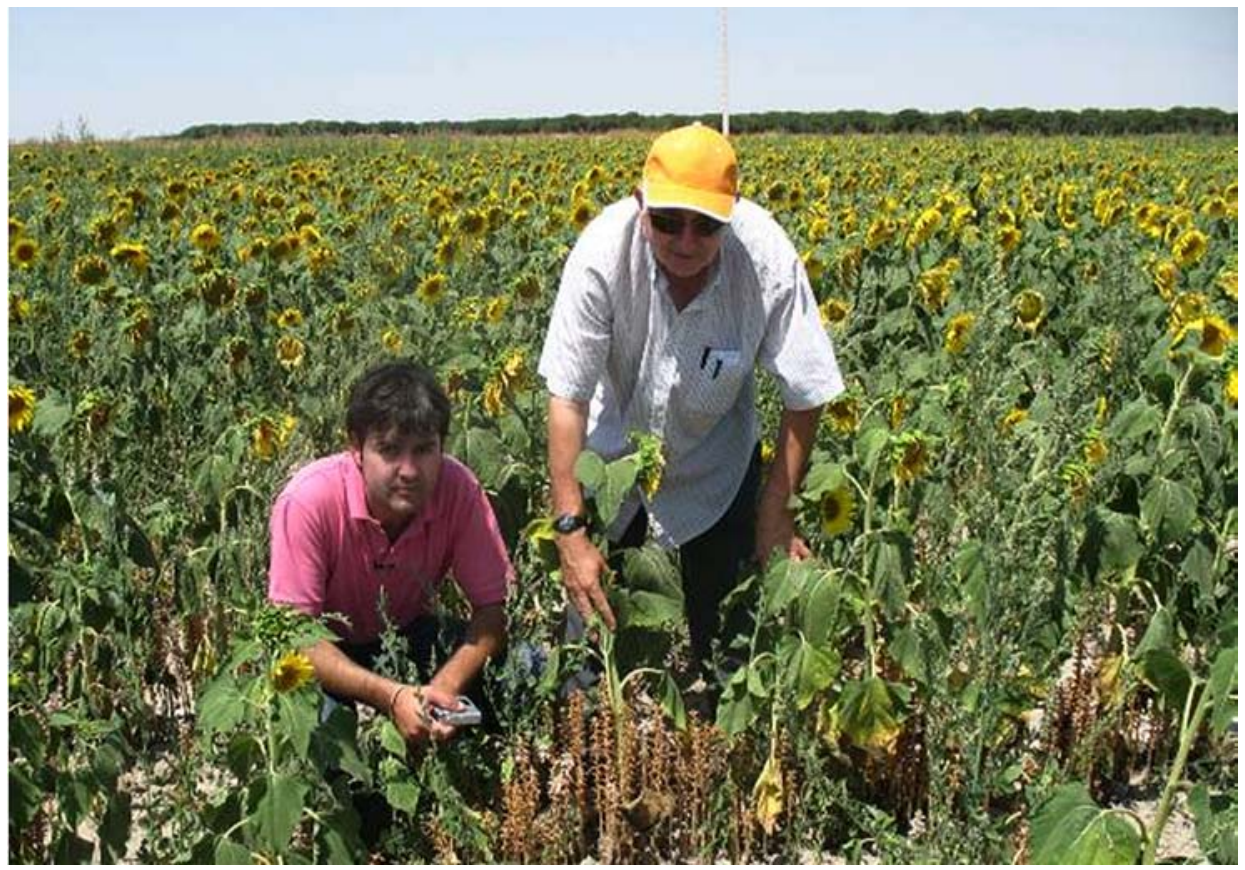

Figure 2: Koipesol team visiting the main focus of broomrape infection

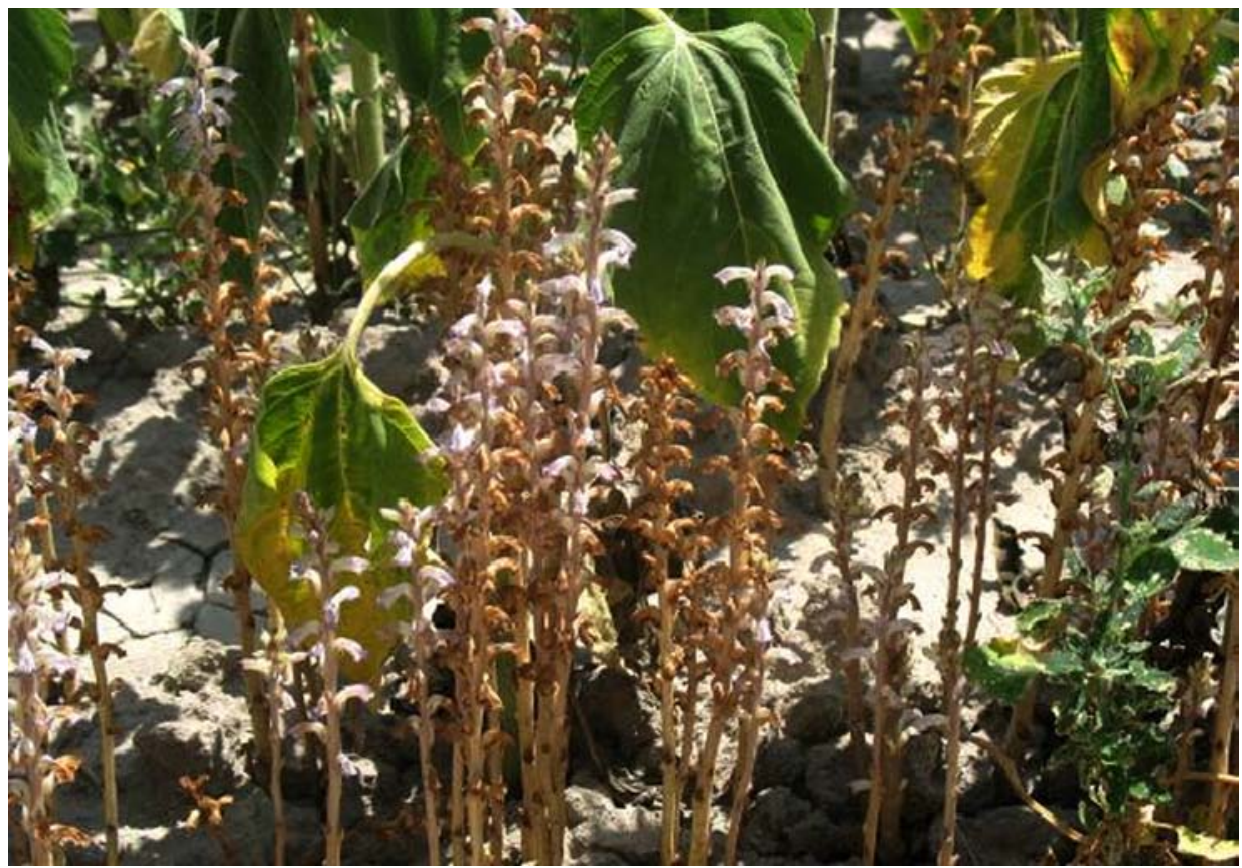

Figure 3: Broomrape infection in the main focus 
The presence of broomrape race $\mathrm{F}$ in some small plots near Écija, in the Guadalquivir valley, was detected in 1995 (Alonso et al., 1996). From that moment on, until the beginning of the year 2000, this infection was located in a small plot $20 \mathrm{~km}$ away from Écija and in a few small plots in Cuenca (Domínguez, 2004). In the years following the year of 2000, race $\mathrm{F}$ became widely dispersed in both the Guadalquivir valley and Cuenca area. For instance, in the Guadalquivir valley, most of the sunflower grown in rainfed conditions was affected by broomrape race $F$ with a high or low infestation rate (Fernández-Escobar et al., 2008).

The sunflower/broomrape situation in Spain evolved in the last 50 years through different dissemination waves, which developed simultaneously in two of the three most important sunflower cultivation areas, Guadalquivir and Cuenca. In the third area, Castilla y León, the broomrape presence had not been observed until now.

\section{MATERIAL AND METHODS}

Orobanche cumana seeds were collected from Orobanche inflorescences parasitizing sunflower plants grown in a commercial field in Medina del Campo (Valladolid). This broomrape population was assigned the code EK 156. In order to determine to which race it belonged, the following sunflower differential lines and varieties were used: VYP, a hybrid highly susceptible to all sunflower broomrape races, P1380 carrying the $\mathrm{Or}_{5}$ gene, which gives resistance up to race E, KI-374, an inbred line from Koipesol Semillas (Rodríguez-Ojeda, 2001), carrying two recessive genes $\left(\mathrm{or}_{6}\right.$ and $o r_{7}$ ) which provide resistance up to race $\mathrm{F}$, and the three $\mathrm{F}$-resistant commercial hybrids most widely spread in Spain (R-Hy 1, R-Hy 2 and R-Hy 3).

All of them were tested against two different sunflower broomrape isolates EK 146, F race from Andalusia, used in the Koipesol laboratory for routine broomrape race $\mathrm{F}$ tests. and the EK 156, a population collected in Medina del Campo.

The sunflower reaction to broomrape was evaluated by the methods described in Rodriguez-Ojeda et al. (2001). The percentage of infested sunflower plants (incidence) and the number of broomrapes per infested sunflower plant (disease severity) were measured on bare roots 45 days after sowing time. The number of sunflower plants per treatment was 20 .

\section{RESULTS AND DISCUSSION}

In the 2008 season, a sunflower grower Joaquín Sobrino requested a visit of a Koipesol technical team due to the presence of some unusual weeds in his field, which turned out to be Orobanche cumana Wallr. The broomrape was found in an 8 ha sunflower field near Medina del Campo (Valladolid, south-centre of Castilla y León sunflower area). 
A survey showed that there were four focal points of broomrape presence. The main one, with a surface of about $300 \mathrm{~m}^{2}$, had a high infestation rate, with all sunflower plants showing more than 20 broomrapes per plant (Figures 2 and 3). In the other three focal points, the broomrape infestation was lower, with 0-15\% of sunflower plants being infected by 1 or 2 broomrapes per plant. Some broomrape isolates were found in the remaining part of the field, but no broomrape was found in neighboring fields. Therefore, the broomrape presence in Medina del Campo seemed to be concentrated on Joaquin Sobrino's farm.

As is usual in that area, the sunflower was rotated in this field with a cereal or fallow, and during the last ten years it was planted in 2002, 2004, 2006 and 2008. The broomrape distribution on this farm led us to assume that the first broomrape infestation took place in the main focal point in 2004. In 2006, an important multiplication of the broomrape inoculum took place together with its dispersion to the remaining parts of the field, probably by wind and/or tillage equipment.

The reaction of differential sunflowers lines towards the broomrape population EK 156 collected in Medina del Campo and the population EK 146 belonging to race $F$, which was used as a check, was similar (Table 1 ). The highly susceptible hybrid (VYP) and the line P1380 (Or 5 gene) were infested and while the line and hybrids with a different race $\mathrm{F}$ resistance remained uninfested. This behaviour indicates that the inoculum EK 156, harvested in Medina del Campo, is race F. The attacking rate of the new isolate EK 156 was considerably higher than that of EK 146, which means that it is more aggressive than our $\mathrm{F}$ race check.

If the distribution and dissemination pattern of broomrape race $\mathrm{F}$ in the Guadalquivir valley (Fernandez-Escobar et al., 2008) is used as a model, the future evolution of sunflower broomrape in Castilla y León could be as follows. The infested surface near Medina del Campo will increase in the next 2-3 years, and it won't be possible to grow non $\mathrm{F}$ race-resistant hybrids in further 3-5 years in that area. An extensive dissemination in other areas of Castilla-León could take place in the next 10 years. Finally, after 12-15 years, the situation could be similar to that of the Guadalquivir valley at present, where only $20-25 \%$ of the fields are free from broomrape race $\mathrm{F}$.

Table 1: Reaction of differential sunflower lines to two broomrape populations, from the Guadalquivir valley and Medina del Campo

\begin{tabular}{lcccc}
\hline Sunflower dif- & \multicolumn{4}{c}{ Broomrape population } \\
\cline { 2 - 5 } ferential line or \\
\cline { 2 - 5 } variety & \multicolumn{2}{c}{ EK 146 (Guadalquivir) } & EK 156 (Medina del Campo) \\
\cline { 2 - 5 } & Incidence & Disease severity & Incidence & Disease severity \\
\hline VYP & 100 & 10.90 & 100 & 35.90 \\
P 1380 & 100 & 3.60 & 100 & 11.30 \\
KI-374 & 0 & 0 & 0 & 0 \\
R-Hy-1 & 0 & 0 & 0 & 0 \\
R-Hy-2 & 0 & 0 & 0 & 0 \\
R-Hy-3 & 0 & 0 & 0 & 0 \\
\hline
\end{tabular}


In order to delay the broomrape dissemination in Castilla y León, keeping the sunflower production in this area at the current level, an effective strategy could be the use of sunflowers resistant to imidazolinone herbicide (IMI sunflowers). The utilization of IMI sunflower along with herbicide treatment offers an effective control of broomrape whatever the pathotype might be (Alonso et al., 1998), since this combination prevents the multiplication and dissemination of the pathogen. In Castilla y León the IMI sunflower hybrids have been proved to perform similarly to the standard non-resistant hybrids (personal data).

\section{REFERENCES}

Alonso, L.C., Fernández-Escobar, J., López, G., Rodríguez-Ojeda, M.I. and Sallago, F., 1996. New highly virulent sunflower broomrape (Orobanche cernua Loelf.) pathotypes in Spain. In: Moreno, M.T., Cubero, J.I., Berner, D. Joel, D. Musselman, L. and Parker, C. [Eds], Advances in Parasitic Plant Research. Proc. $6^{\text {th }}$ Int. Symp. Parasitic Weeds. Córdoba, Spain, 16-18 April, 1996. pp. 639-644.

Alonso, L.C., Rodríguez-Ojeda, M.I. and Fernández-Escobar, J., 1998. Chemical control of broomrape (Orobanche cernua Loefl.) in sunflower (Helianthus annuus L.) resistant to imazethapyr herbicide. Helia 21(29): 45-54.

Domínguez, J., 1996. Estimating effects on yield and other agronomic parameters in sunflower hybrids infested with the new races of sunflower broomrape. In: Proc. Symposium on Disease Tolerance in Sunflower, Beijing, China, International Sunflower Association, Paris. pp. 118-123.

Domínguez, J., 2004. Visión actual de las infestaciones del cultivo del girasol por jopo. Vida Rural 55: 12-15.

Fernández-Escobar, J., Rodríguez-Ojeda, M.I. and Alonso L.C., 2008. Distribution and dissemination of sunflower broomrape (Orobanche cumana Wallr.) race F in Southern Spain. $17^{\text {th }}$ International Sunflower Conference, Córdoba, Spain. Vol. 1: 231-236.

González-Torres, R., Jiménez-Diaz, R. and Melero-Vara, J.M., 1982. Distribution and virulence of Orobanche cernua in sunflower crops in Spain. Phytopath. Z. 104: 78-89.

Melero-Vara, J.M., 1999. Pathogenic variability in Orobanche cumana Wallr. In: Cubero, J.I., Moreno, M.T., Rubiales, D. and Sillero, J., [Eds] Resistance to Orobanche: The state of the art. Consejería de Agricultura y Pesca, Junta de Andalucía, Congresos y Jornadas 51/99, Sevilla, Spain pp. 149-155.

Melero-Vara, J.M., Dominguez J., and Fernández-Martínez, J.M. 2000. Update on sunflower broomrape situation in Spain: Racial status and sunflower breeding for resistance. Helia 23: 45-56.

Parker, C., 1994. The present state of Orobanche problem. In: Pieterse, A.H., Verkleijand, J.A.C. and Borgs, T., [Eds], Biology and Management of Orobanche and Related Striga Research, Royal Tropical Institute, Amsterdam. pp. 17-26.

Rodríguez-Ojeda, M.I., Fernández-Escobar, J. Alonso, L.C., 2001. Sunflower inbred line (KI 374), carrying two recessive genes for resistance against a highly virulent Spanish population of Orobanche cernua Loelf / O. cumana Wallr. race " $F$ ". $7^{\text {th }}$ International Parasitic Weeds Symposium. 5-8 June. Nantes. p. 208.

Sackston, W.E., 1992. On a treadmill: breeding sunflower for resistance to disease. Ann. Rev. Phytopathol. 30: 529-551. 


\title{
PRESENCIA DE JOPO DE GIRASOL (Orobanche cumana Wallr.) EN CASTILLA Y LEÓN, UNA REGIÓN DEL NORTE DE ESPAÑA TRADICIONALMENTE NO INFESTADA POR JOPO
}

\author{
RESUMEN
}

La superficie de girasol cultivada en España está básicamente distribuida en tres áreas aisladas, el Valle del Guadalquivir en el sur que representa un 37 $\%$ de la superficie total cultivada, el área de Cuenca en la meseta central de España, con el 28 \% y el área de Castilla-León en el Norte con el 29 \%. El jopo de girasol (Orobanche cumana, Wallr.) ha estado presente en España desde 1960. Desde entonces, se han producido diferentes oleadas de diseminación y dispersión del parásito. La última correspondió a la dispersión de la raza $\mathrm{E}$ al comienzo de 1990 y de la raza $\mathrm{F}$ en los primeros años del 2000. Estas oleadas de dispersión han estado circunscritas solo a las áreas del Guadalquivir y Cuenca. En el área de Castilla-León la presencia de jopo no ha sido detectada hasta ahora.

En 2008, una virulenta infección focalizada en un punto (alrededor de $300 \mathrm{~m}^{2}$ ) ha sido detectada en una parcela de girasol cerca de Medina del Campo (Valladolid) al sur de la zona centro del área de Castilla-León. La determinación racial demostró que este inóculo de jopo pertenece a la raza $\mathrm{F}$.

\section{OROBANCHE DU TOURNESOL (Orobanche cumana Wallr.) EN CASTILLE-LEÓN, UNE ZONE TRADITIONNELLEMENT SAINE EST INFESTÉE AU NORD DE L'ESPAGNE}

\author{
RÉSUMÉ
}

La surface cultivée de tournesol en Espagne peut être schématiquement divisée en trois principaux secteurs isolés : la vallée de Guadalquivir, en Espagne méridionale qui représente $37 \%$ du total, la région de Cuenca située dans le plateau central, $28 \%$, et la région de la Castille-León, au Nord, $29 \%$.

L'Orobanche du tournesol (Orobanche cumana Wallr.) est présente en Espagne depuis les années 60. Depuis, différentes vagues de diffusion et dispersion du parasite se sont produites. Les plus récentes correspondent à la dispersion de la race $\mathrm{E}$ au début des années 90 et de la race $\mathrm{F}$ au début des années 2000. Ces vagues de diffusion de l'Orobanche ont été circonscrites aux seules régions de Guadalquivir et de Cuenca. En Castille-León, la présence d'Orobanche n'a pas été notée jusqu'à ce jour.

En 2008, un point d'infection particulièrement virulente d'environ $300 \mathrm{~m}^{2}$ a été détecté dans une parcelle de tournesol près de Medina del Campo (Valladolid), sud du centre de la région Castille-León. L'analyse a montré que cet inoculum d'Orobanche appartenait à la race $\mathrm{F}$. 
